\title{
Population Estimation of Grey Francolin (Francolinus pondicerianus) in Salt Range, Punjab, Pakistan
}

Sangam Khalil*, Maqsood Anwar and Iftikhar Hussain

Department of Wildlife Management, Faculty of Forestry, Range Management and Wildlife, Pir Mehr Ali Shah, Arid Agriculture University Rawalpindi, Rawalpindi 46000, PAKISAN

*Corresponding author's email: sangamuaar@gmail.com Cell \# 0331-5181918

Citation

Sangam Khalil, Maqsood Anwar and Iftikhar Hussain. Population Estimation of Grey Francolin (Francolinus Pondicerianus) in Salt Range, Punjab, Pakistan. Pure and Applied Biology. Vol. 4, Issue 4, 2015, pp 584-596. http://dx.doi.org/10.19045/bspab.2015.44018

Received: $14 / 08 / 2015$

Revised: 03/11/2015

Accepted: $12 / 11 / 2015$

\section{Abstract}

The genus Francolinus belongs to Order Galliformes and Family Phasianidae and is diverse genus of game birds. Grey francolin (Francolinus pondicerianus) belongs to this genus and is a medium size game bird, serving as an operator of biological control. Population of grey francolin has declined over the time mainly due to excessive hunting and habitat destruction. Research studies have not been carried out on Grey francolin in the Salt Range and data on their biological and ecological aspects is lacking. The current study was conducted in two protected areas i.e. Chumbi Surla Wildlife Sanctuary (CSWS) and Diljabba Domeli Game Resrve (DDGR) to generate information about population density and distribution pattern of Grey francolin in the Salt Range. For population estimation, 40 transects were laid in the both areas and Grey francolin population were recorded both by direct sighting and calls and data was analyzes by DISTANCE Software 6.0. Significant difference was recorded in population densities among different sites both by sighting and calls method. In CSWS, population density by sighting was the highest at Open land habitat (3.23 individual $\mathrm{ha}^{-1}$ ) while lowest at cultivated habitat (1.58 individual $\left.\mathrm{ha}^{-1}\right)$ and by calls was the highest at (2.87 individual ha-1) from natural forest habitat, while lowest at (1.59 individual $\mathrm{ha}^{-1}$ ) from cultivated habitat. In DDGR population density by sighting was highest from wetland (2.47 individual ha- ${ }^{-1}$ ) and lowest at ( 2.09 individual ha-1 $)$ from natural forest habitat, by calls highest from open land habitat $\left(2.45\right.$ individual ha $\left.^{-1}\right)$ and lowest from wetland habitat (1.10 individual $\mathrm{ha}^{-1}$ ). This study would provide essential scientific base about population and distribution patterns of grey francolin in the study area that is required for the conservation of grey francolin, ultimately helping in sustaining the population of this important game bird in the Salt Range.

Key words: Chumbi Surla; Density; Diljabba Domeli; Distance software 6.0; Francolinus; Game bird.

\section{Introduction}

Pakistan has variety of ecosystems with diverse avifauna [1]. More than 650 bird species have been reported in the country and their occurrence is unique in the world as diversity of habitat found here $[2,3]$. Grey francolin (Francolinus pondicerianus), formerly called grey partridge [4] is a 
medium-sized game bird of Family Phasianidae and is found in open, dry and arid parts of the Asia [4, 5]; Pakistan, southeastern Iran, India, Bangladesh and northern Sri Lanka. Its origin allowed it to live easily in cultivated areas where it can find cover, food, and ground for nesting [6, 7]. Grey francolin is native bird of Pakistan $[8,4,9]$, however, under different environmental conditions shows local migration. In Pakistan, Grey francolin is widely distributed from the west of Indus valley to south of the foothills of Himalayas [4]. It is rarely found above an elevation of $1200 \mathrm{~m}$ in Pakistan and usually found feeding on bare soil or low grass cover in open and scrub country [10].

This species is considered "friend of the farmers" as it consumes variety of invertebrates including, insects, their eggs, larvae and pupa, which are harmful to crops and, therefore, work as effective biocontrolling agent $[11,12]$. It is an excellent game and table bird, also used as a cage and fighting bird [13].

They may roost at night on low thorny branches of trees or shrubs in pairs or family groups called "coveys" and have camouflaging plumage to live in vegetation that is not so dense [14, 4]. Grey francolin is an indicator species for farmland ecosystems and decline in its population has been reported in the past $[15,9]$. Increased use of pesticides due to agriculture expansion and habitat degradation can be cited as main causes behind its decline. A rapid decline in its natural habitat has been reported by [4], through its food loss, excessive predation, habitat destruction, intensification of agricultural practices and pressure on scrub forests for use as fodder, timber wood and fire wood needs. It is listed Least Concern on IUCN Red List, one of the reasons behind this is that it has a wider distribution range [16].
Unfortunately, in the past very few studies addressed grey francolin found in different parts of Pakistan. None of those was carried out in Salt Range of the Punjab, one of the major areas of its distribution in Pakistan. Keeping in view the declining trend in population of grey francolin, current study was conducted to generate information about population density, distribution pattern of grey francolin in different habitat types in the study area.

\section{Materials and Methods Study area}

The study was conducted at Chumbi Surla Wildlife Sanctuary (CSWS) and DiljabbaDomeli Game Reserve (DDGR) located in Salt Range, Pakistan (Figure 1). The Salt Range is an east-west turning point of communication about $175 \mathrm{~km}$ long in the northern Punjab consisting of Khushab, Mianwali, Jhelum and Chakwal districts [17]. It extends between $32^{\circ} 41-32^{\circ} 56 \mathrm{~N}$ and $71^{\circ} 50-74^{\circ} \mathrm{E}$, elevation $250 \mathrm{~m}-1520 \mathrm{~m}$ and forms an impressive scarp. Sakesar top is the highest point in Salt Range with an elevation of $1524 \mathrm{~m}$ [18].

Chumbi Surla Wildlife Sanctuary is situated at $20 \mathrm{~km}$ south- west of Chakwal Town at $32^{\circ} 47 \mathrm{~N} \& 67^{\circ} 42 \mathrm{E}$ and $460 \mathrm{~m}-1050 \mathrm{~m}$ elevation . Total area of CSWS is 55,987 ha [19]. The sanctuary contains different habitat types including; wetlands, torrents, farm lands and hills, due to whaich good diversity of wild animals exist here. Climate of CSWS is dry sub-tropical with cool winters and hot summers. Temperature ranges from $10^{\circ} \mathrm{C}$ to $41{ }^{\circ} \mathrm{C}$ and average annual rainfall is $500 \mathrm{~mm}$ [20]. The sanctuary has mixture of sub-tropical semievergreen and tropical thorn forest [19]. Diljabba- Domeli Game Reserve is located in district Jhelum at $32^{\circ} 54 \mathrm{~N}-73^{\circ} 09 \mathrm{E}$ and $600 \mathrm{~m}$ elevation. Total area of the game reserve is 118,106 ha [18]. 
Pure Appl. Biol., 4(4): 584-596, December- 2015 

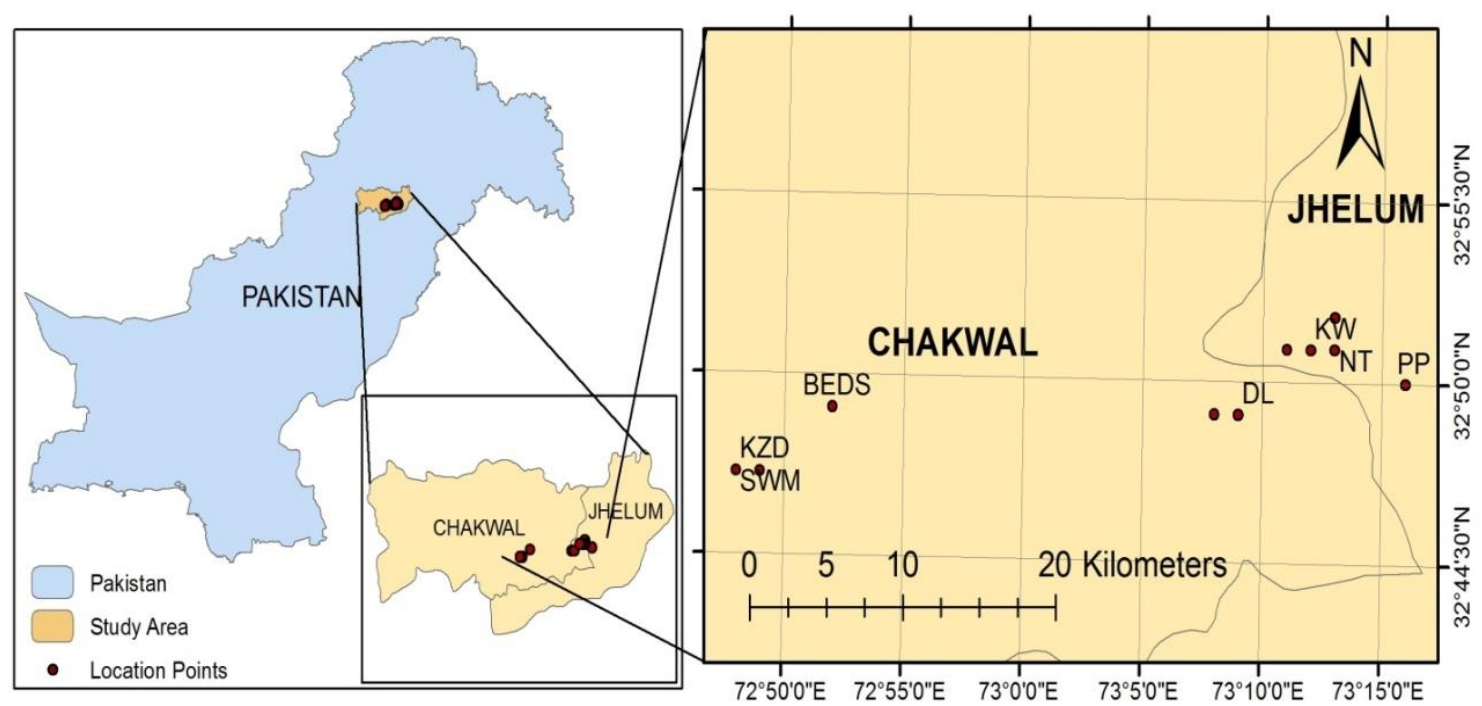

Figure 1. Map showing study area and sites selected for data collection within Salt Range.

\section{Methodology}

A reconnaissance survey was conducted to select the study sites for data collection within two study areas i.e. Chumbi Surla Wildlife Sanctuary and Diljabba- Domeli Game Reserve as representatives of Salt Range. Study sites were selected for data collection, on the basis of occurrence of grey francolin and accessibility of the area. Study area was divided into different habitat types as potential sites for the grey francolin. Different types of potential habitats of grey francolin found in the study area were randomly selected for collecting data including; I) cultivated crop fields and associated natural vegetation on field boundaries, II) natural forest and associated grassland, III) open lands, and IV) wetlands and associated natural vegetation.

Population estimation in selected habitats For population estimation of Grey francolin, direct sightings of the birds using "Visual Encounter Method (VEM)" and call counts were used in four selected habitat types Five permanent transects of $0.5 \mathrm{~km}$ to $3 \mathrm{~km}$ in length and $100 \mathrm{~m}$ (50 m on each side) in width were established, adjusting length and orientation of transect based on terrain of the site. Tansects were taken between $539 \mathrm{~m}$
(Bella), 687 m (Khokhar Zer Dam), 697 m (Dhok Sehla) and $708 \mathrm{~m}$ (SubedaraWali Mori) in CSWS and between $395 \mathrm{~m}$ (Pathial Pahar), $460 \mathrm{~m}$ (Kalewali), $463 \mathrm{~m}$ (Nathoot) and $505 \mathrm{~m}$ (Dhial) in DDGR. Transects were walked slowly by single observer in every month for four successive days, both in the morning (from 5 am to 8 am during April to September in summer and from 6 am to 10 am during October to March in winter) and the evening (from $5 \mathrm{pm}$ to $8 \mathrm{pm}$ during April to September in summer and from $2 \mathrm{pm}$ to 5 pm during October to March in winter) to record direct sighting or calls of grey francolin depending on topography of land and nature of vegetation [21]. Population density for each site was calculated separately using by the sightings and call counts data. During breeding season calls were more prominent than direct sighting, so call counts method was also used for population estimation.

\section{Estimation from direct Sighting}

Estimation of Grey francolin population was carried out by direct sighting of the birds along the transects. For every observation, sighting angle (perpendicular distance from observer to bird) was recorded and distance 
from observer to the francolin was measured.

\section{Estimation from call count method}

For estimation of Grey francolin population call counts method [22] was used. Calls of Grey francolin were counted in each sample area early in the morning and evening. Grey francolin was assumed to have pairing for mating during spring season. Each call was recorded individually by assuming that male grey francolin produced calls especially during breeding season. During observations utmost care was taken in data recording to avoid overlapping as only those birds on transect were recorded who fall under transect line.

Both sighting and call count methods of population assessment were used to compare the effectiveness of methods under CSWS and DDGR conditions. Forty permanent line transect of $0.5-3 \mathrm{~km}$ length was used. Transect line was walked with uniform speed for four successive days during different month of study period in the morning hours from 5 am to 8 am and the evening hours from $5 \mathrm{pm}$ to $8 \mathrm{pm}$. Numbers of grey francolin for each transect walk were recorded from sighting and calls. To work out the total number of calls and sightings for each month and for each time period (morning / evening), respective data for different transects were averaged / combined. Transect length being variable, frequencies obtained from sighting and calls for different time periods and months were directly compared to observe the differences in population of grey francolin between different sites/habitats by ANOVA at 0.05 level of significance as used by [23].

For population estimation, DISTANCE version 6.0 was used $[24,25,26]$. The priori models (Key function/ sries expansion) used to arrive at density estimates included; Uniform - cosine, Half normal-Hermite polynomial and Hazard rate - Simple polynomial. Model selection was at the minimum of Akaike information criterion (AIC). As AIC provides a relative measure of fit. Distance also provides the $\triangle \mathrm{AIC}$ values, with the AIC of best fitted model which are the values of AIC subtraction. Thus change in AIC is equal to zero for the best model [26]. The density estimation was made by pooled data of over all individuals encountered at transects.

\section{Results and Discussion}

\section{Population estimation of Grey francolin}

Area of Grey francolin habitat in scrub forest considered for distance sampling extended from Dhok Shela $\left(32^{\circ} 47.869^{\prime \prime} \mathrm{N}\right.$, $72^{\circ} 48.659$ "E) to Khokhar Zer Dam (32 49.591 "N, $72^{\circ} 52.023$ "E), in CSWS and from Pathial Pahar $\left(32^{\circ} 50.131 \mathrm{~N}, 73^{\circ}\right.$ $16.053 \mathrm{E}$ ) to Kalewali (32 $51.544^{\circ} \mathrm{N}, 73^{\circ}$ 12.651" E) in DDGR (Table 1). Total 40 transects were laid in both areas and Grey francolin population were recorded both by direct sighting and calls counts.

Table 1. Selected study sites for Grey Francolin population estimation in Salt Range.

\begin{tabular}{lllcll}
\hline $\begin{array}{l}\text { Study } \\
\text { Area }\end{array}$ & Location & Habitat Type & Elevation & Coordinates & \\
CSWS & Dhok Sehla & Natural Forest & $697 \mathrm{~m}$ & $32^{\circ} 47.869 \mathrm{~N}$ & $72^{\circ} 48.659 \mathrm{E}$ \\
& SubedaraWali Mori & Cultivated Field & $708 \mathrm{~m}$ & $32^{\circ} 47.775 \mathrm{~N}$ & $72^{\circ} 48.582 \mathrm{E}$ \\
& Bella & Open land & $539 \mathrm{~m}$ & $32^{\circ} 49.595 \mathrm{~N}$ & $72^{\circ} 52.127 \mathrm{E}$ \\
& Khokhar Zer Dam & Wetland & $687 \mathrm{~m}$ & $32^{\circ} 49.591 \mathrm{~N}$ & $72^{\circ} 52.023 \mathrm{E}$ \\
DDGR & Pathial Pahar & Natural Forest & $395 \mathrm{~m}$ & $32^{\circ} 50.131 \mathrm{~N}$ & $73^{\circ} 16.053 \mathrm{E}$ \\
& Nathoot & Cultivated Field & $463 \mathrm{~m}$ & $32^{\circ} 51.761 \mathrm{~N}$ & $73^{\circ} 11.941 \mathrm{E}$ \\
& Dhial & Open land & $505 \mathrm{~m}$ & $32^{\circ} 49.883 \mathrm{~N}$ & $73^{\circ} 09.406 \mathrm{E}$ \\
& Kalewali & Wetland & $460 \mathrm{~m}$ & $32^{\circ} 51.544 \mathrm{~N}$ & $73^{\circ} 12.651 \mathrm{E}$ \\
\hline
\end{tabular}


Population density in salt range by direct sighting

Estimated population density by direct sighting was 3.07 individual $\mathrm{ha}^{-1}$ (95\% CI: 0.47 and 0.72) from Dhok Shela, 1.85 individual $\mathrm{ha}^{-1}$ (95\% CI: 0.48and 0.82) from Subedarawali Mori, 3.23 individual $\mathrm{ha}^{-1}$ (95\% CI: 0.45 and 0.71) from Bella, 3.19 individual ha ${ }^{-1}$ (95\% CI: 0.45 and 0.65 ) from Khokhar Zer Dam. Population were recorded through sighting in DDGR; 2.09 individual ha ${ }^{-1}(95 \%$ CI: 0.50 and 0.90$)$ from Pathial Pahar, from Nathoot 2.51 individual $\mathrm{ha}^{-1}$ (95\% CI: 0.45 and 0.68), from Dhial 2.45 individual $\mathrm{ha}^{-1}$ (95\% CI: 0.44 and 0.70 ) and from Kalewali 2.47 individual $\mathrm{ha}^{-1}(95 \%$ CI: 0.45 and 0.68 ). Population density by sighting was the highest (3.23 individual ha$\left.{ }^{1}\right)$ at Bella while lowest at Subedarawali Mori (1.58 individual $\mathrm{ha}^{-1}$ ). In DDGR by sighting population was highest from Kalewali 2.47 individual $\mathrm{ha}^{-1}$ and lowest at 2.09 individual $\mathrm{ha}^{-1}$ from Pathial Pahar.Effective width of transect for sighting in CSWS was 41.12 (Dhok Shela), 44.38 (Subedarawali Mori) 25.67 (Bella), and 24.69 (Khokhar Zer Dam). In DDGR, effective width of transect for sighting was 43.74 (Pathial Pahar), 25.13 (Nathoot), 25. 37 (Dhial), 25. 05 (Kalewali) (Table 2).

Table 2. Summary of model used and fit in line transect analysis of Grey Francolin by sighting.

\begin{tabular}{cllccc}
\hline $\begin{array}{c}\text { Name of } \\
\text { Sites }\end{array}$ & \multicolumn{1}{c}{ Location } & $\begin{array}{c}\text { Population } \\
\text { Estimation Model }\end{array}$ & AIC & ESW/EDR & D/Hac \\
CSWS & Dhok Sehla & $\begin{array}{l}\text { Uniform / cosine } \\
\text { DSh }\end{array}$ & 289.58 & 41.12 & 3.074 \\
& Subedara Wali & Uniform / cosine & 259.67 & 44.38 & 1.856 \\
& Mori & & & & \\
& Bella & Uniform / cosine & 221.54 & 25.67 & 3.231 \\
& Khokhar Zer Dam & Uniform / cosine & 211.89 & 24.69 & 3.199 \\
DDGR & Pathial Pahar & Uniform / cosine & 306.80 & 43.74 & 2.097 \\
& Nathoot & Uniform / cosine & 168.63 & 25.13 & 2.516 \\
& Dhial & Uniform / cosine & 161.96 & 25.37 & 2.458 \\
& Kalewali & Uniform / cosine & 198.59 & 25.05 & 2.476 \\
\hline
\end{tabular}

Population density in salt range by calls By calls population estimation from CSWS was 2.87 individual ha ${ }^{-1}$ (95\% CI: 0.56 and 1.00) from Dhok shela, 1.59 individual $\mathrm{ha}^{-1}$ (95\% CI: 0.51 and 0.88 ) from Subedarawali Mori, 2.17 individual ha ${ }^{-1}$ (95\% CI: 0.50 and 0.96) from Bella, 1.88 individual ha ${ }^{-1}(95 \%$ CI: 0.44 and 0.69) from Khokhar Zer Dam . In DDGR, by calls 1.99 individual ha ${ }^{-1}(95 \%$ CI: 0.50 and 0.90) from Pathial Pahar, from Nathoot 1.25 individual ha ${ }^{-1}$ (95\% CI: 0.45 and 0.92), from Dhial 2.45 individual ha ${ }^{-1}$ (95\% CI: 0.43 and 0.75) and from Kalewali 1.10 individual $\mathrm{ha}^{-1}$ (95\% CI: 0.42 and 0.79). By calls highest population was recorded from Dhial 2.45 individual ha ${ }^{-1}$ and lowest from Kalewali 1.10 individual $\mathrm{ha}^{-1}$ in DDGR. By call count method, population was the highest at Dhok sehla (2.87 individual ha $\left.\mathrm{h}^{-1}\right)$ while lowest at $(95 \%$ CI: 0.51 and 0.88$)$ at Subedarawali Mori (1.59 individual ha ${ }^{-1}$ ) in CSWS. For calls effective width of transect was 45.92 (Dhok Shela), 47 was at (Subedarawali Mori), 48.54 (Bella), and 33.54 (Khokhar Zer Dam) in CSWS. In DDGR, effective width of transect for calls was 43.74 (Pathial Pahar), 45.69 (Nathoot), 34.35 (Dhial) and 35.0 (Kalewali) (Table 3). 
Table 3. Summary of model used and fit in line transect analysis of Grey Francolin by calls.

\begin{tabular}{|c|c|c|c|c|c|}
\hline $\begin{array}{l}\text { Name of } \\
\text { Sites }\end{array}$ & Location & $\begin{array}{c}\text { Population } \\
\text { Estimation } \\
\text { Model }\end{array}$ & AIC & ESW/EDR & D/Hac \\
\hline \multirow[t]{6}{*}{ CSWS } & Dhok Sehla & Uniform / cosine & 409.11 & 45.92 & 2.879 \\
\hline & Subedara wali & & 337.05 & 47.14 & 1.599 \\
\hline & Mori & Uniform / cosine & & & \\
\hline & Bella & Uniform / cosine & 262.25 & 48.54 & 2.179 \\
\hline & Khokhar Zer & & 183.02 & 33.54 & 1.885 \\
\hline & Dam & Uniform / cosine & & & \\
\hline \multirow[t]{4}{*}{ DDGR } & Pathial Pahar & Uniform / cosine & 306.80 & 43.74 & 1.997 \\
\hline & Nathoot & Uniform / cosine & 194.06 & 45.69 & 1.619 \\
\hline & Dhial & Uniform / cosine & 168.44 & 34.35 & 1.259 \\
\hline & Kalewali & Uniform / cosine & 161.32 & 35.00 & 1.101 \\
\hline
\end{tabular}

There was significant difference in population densities among different sites and habitat types in both study area of CSWS (ANOVA: $\mathrm{F}=6.59$; $\mathrm{df}=3 ; \mathrm{P}=$ 0.008) and DDGR (ANOVA: $\mathrm{F}=6.59$; $\mathrm{df}=$ $3 ; \mathrm{P}=0.042)$ (Table 4). The conventional distance sampling analysis engine was used which models possibility to detect as a distance function from transect line. Distance sampling (Buckland et al., 2001) is an addition in sampling of an area, in which estimation of the birds are made inside fixed range. The expansion in distance sampling gives the chance that some of the birds are not counted present in the area. The detection probability of an animal decreases with increasing distance from transect line (Thomas et al., 2010).

Highest detection probabilities by sighting were 0.71 at Dhok sehla (Figure 2), 0.63 Subedarawali Mori 0.57 at Bella and 0.54 at Khokhar Zer Dam. Probability of detection by calls was 0.76 at Dhok sehla (Figure 3), 0.67 at Subedarawali Mori, 0. 69 at Bella, 0.55 Khokhar Zer Dam. In DDGR detection probabilities by sighting were 0.67 at Pathial Pahar ( Figure 4), 0.55 at Nathoot 0.56 at Dhial and 0.55 at Kalewali , while by calls were 0.67 at Pathial Pahar ( Figure 5), 0.65 at Nathoot , 0.57 at Dhial and 0.58 at Kalewali. 
Table 4. ANOVA table showing difference in population density of Grey Francolin between study sites.

\begin{tabular}{|c|c|c|c|c|c|c|c|c|}
\hline \multirow{2}{*}{$\begin{array}{l}\text { Study } \\
\text { Site }\end{array}$} & \multicolumn{8}{|c|}{ ANOVA-Single Factor } \\
\hline & Groups & Count & Sum & Average & df & $\begin{array}{l}\mathrm{P}- \\
\text { value }\end{array}$ & $\begin{array}{l}\text { F- } \\
\text { critical }\end{array}$ & Level of Sig. \\
\hline \multirow[t]{4}{*}{ CSWS } & $\begin{array}{l}\text { Subedarawali } \\
\text { Mori }\end{array}$ & 2 & 252 & 126 & 3 & 0.008 & 6.59 & $0.05 \%$ \\
\hline & Dhok Sehla & 2 & 400 & 200 & & & & \\
\hline & Bella & 2 & 250 & 125 & & & & \\
\hline & $\begin{array}{l}\text { Khokhar Zer } \\
\text { Dam }\end{array}$ & 2 & 207 & 103.5 & & & & \\
\hline \multirow[t]{4}{*}{ DDGR } & Pathial Pahar & 2 & 180 & 90 & 3 & 0.042 & 6.59 & \\
\hline & Nathoot & 2 & 248 & 124 & & & & \\
\hline & Dhial & 2 & 155 & 77.5 & & & & \\
\hline & Kalewali & 2 & 151 & 75.5 & & & & \\
\hline
\end{tabular}

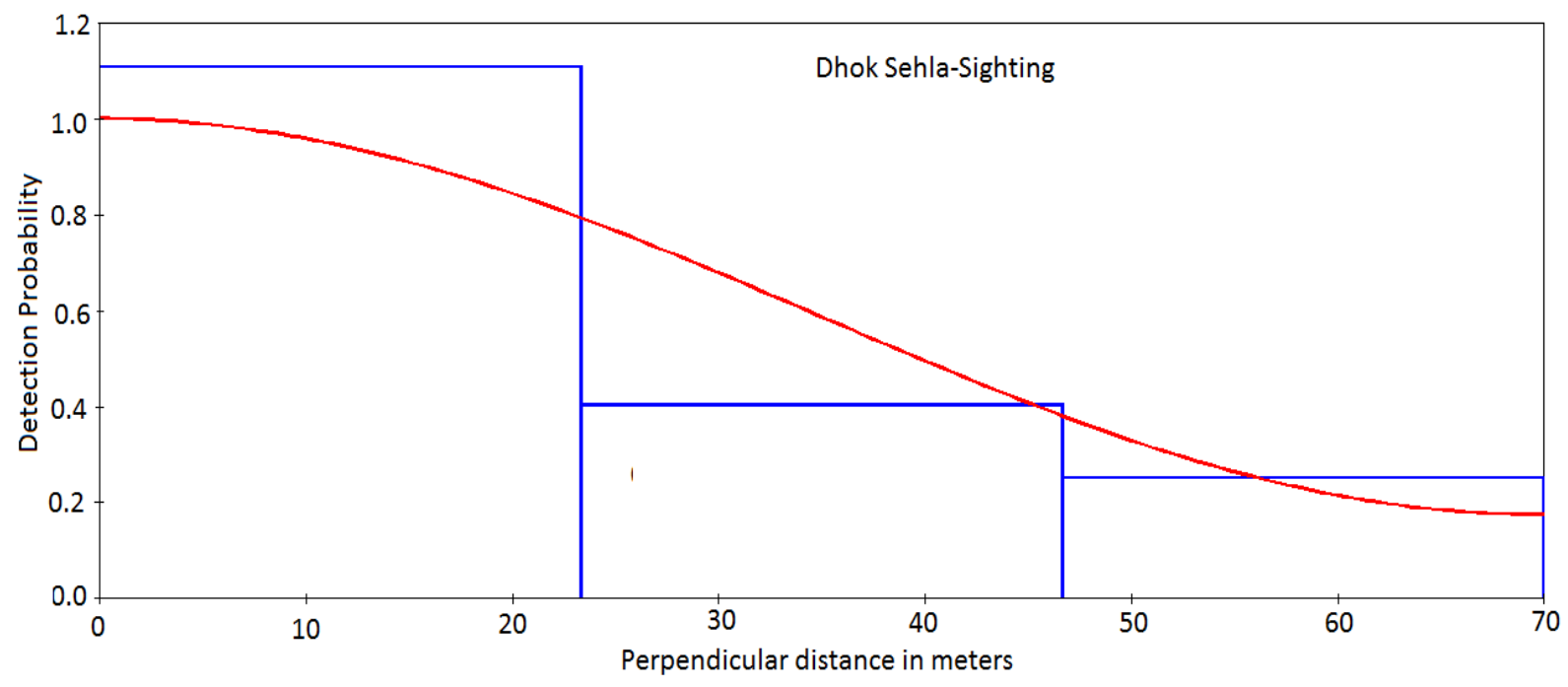

Figure 2. Distance function curve for Grey Francolin sightings in natural forest habitat in Chumbi Surla Wildlife Sanctuary. 


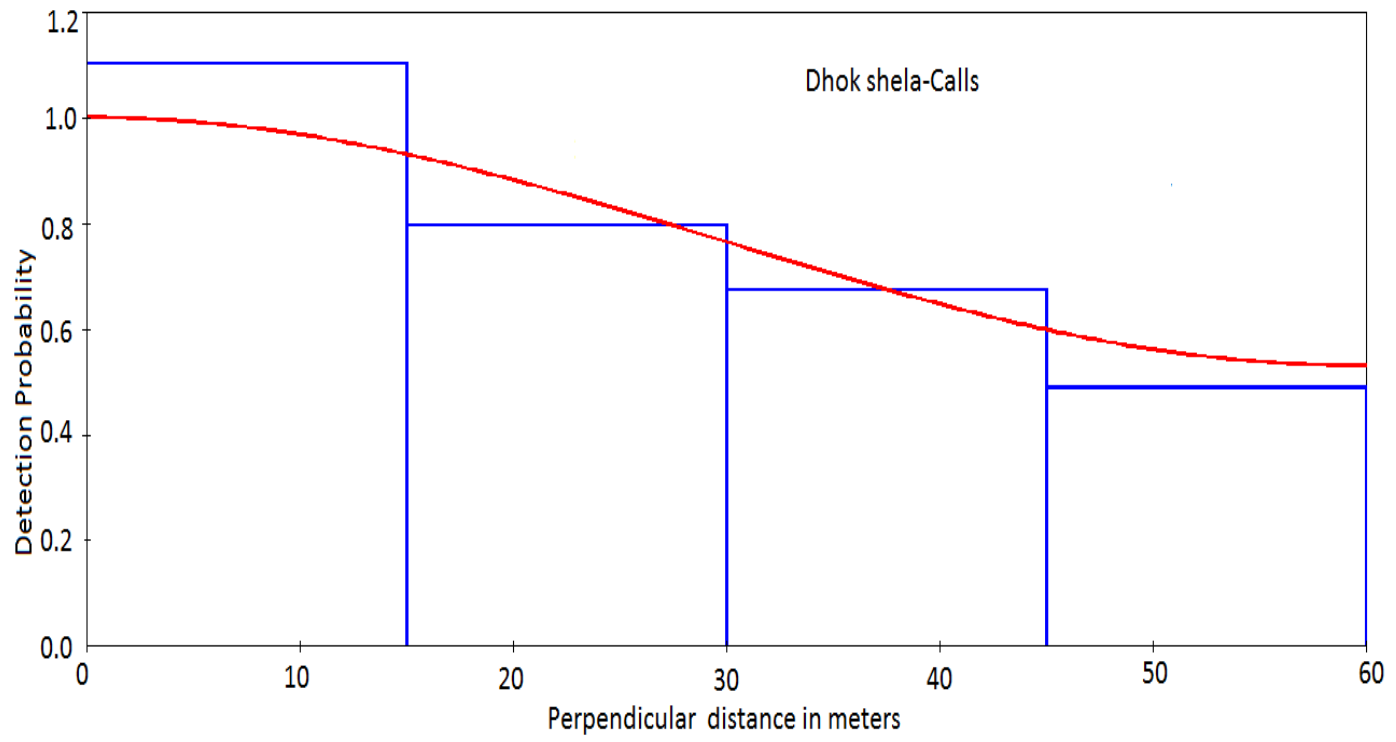

Figure 3. Distance function curve for Grey Francolin calls in natural forest habitat.

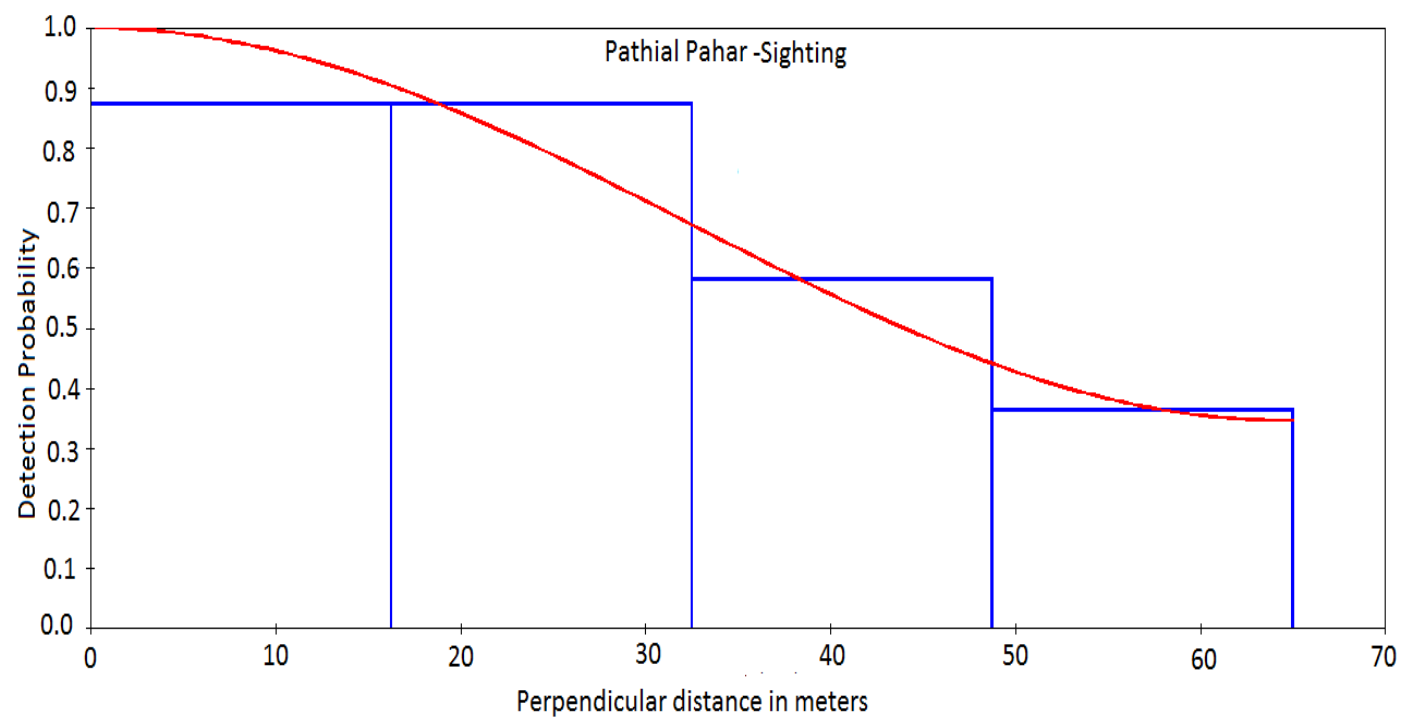

Figure 4. Distance function curve for Grey Francolin sightings in natural forest habitat in Diljabba Domeli Game Reserve. 


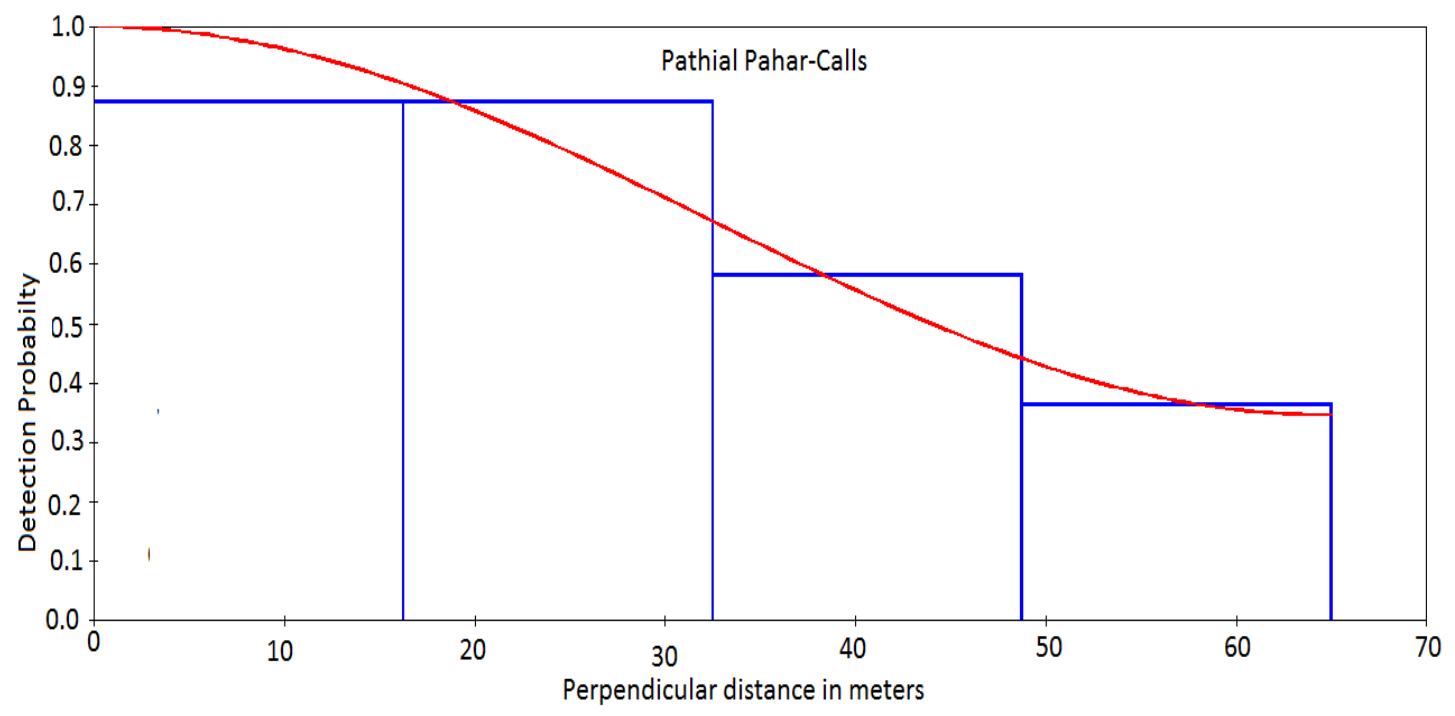

Figure 5. Distance function curve for Grey Francolin calls in natural forest habitat, Diljabba Domeli Game Reserve.

\section{Discussion}

The data collected on the population distribution of Grey francolin revealed that this species was not evenly distributed in different sites of the study area having different elevations and vegetation which is evident from difference in its population density at different locations and habitats of both study areas. Highest population density recorded by sighting in CSWS was at Bella (3.23 individual ha-1) that was an open land with sparse vegetation in the middle of the area, which increased visibility of birds during daily activities and thick vegetation on its boundaries provides cover for them to live in open land habitat.

Lowest population in CSWS was at Subedarawali Mori (1.58 individual $\mathrm{ha}^{-1}$ ) that was cultivated cropland having different cropping pattern during year. In a study conducted in Lal Suhanra National Park (LSNP) [27], reported very low densities of Grey francolin i.e. 0.83 and 0.60 individuals $/ \mathrm{km}^{2}$ in intensively protective desert tracts. [28] estimated 7.44 birds / $\mathrm{km}^{2}$ in LSNP under same desert conditions. According to this study variation in frequencies of calls were prominent as compared to sighting in same area. The difference in population density figures of Grey francolin in this study and that reported previously for LSNP can be associated to variation in sampling designs of both studies. [29] has been reported for the Mannar, Sri Lanka, a relatively low density of population of 3.5 / $\mathrm{km}^{2}$ birds for the Grey francolin. Temperature is considered to be an important factor in deciding the populations of francolins. However new brooders are also matured in summer and ready for calls which causes increase in the population density. Sufficient amount of food also play critical role, besides these factor. For decrease in population of grey francolin, the possible reason seems to be illegal hunting, netting, grazing, industrialization and urbanization. Seasonal fluctuations also affect the population of francolin species. Overall species maintain low population during winter. But the population density of grey francolin starts rising gradually in summer.

By calls method, the highest density was found at Dhok Sehla (2.87 individual ha ${ }^{-1}$ (95\% CI: 0.56 and 1.00), that was natural forest while again lowest density was in Subedarawali Mori at 1.59 individual $\mathrm{ha}^{-1}$ shows that Grey francolin has low 
preference for this type of habitat that has only cultivated crops without water source and scarce natural vegetation in CSWS.

In DDGR by sighting, highest density was estimated for Kalewali (2.47 individual ha-1) which was a wetland area with thick natural vegetation on its boundaries. This indicates that species prefers the habitat having water and thick vegetation, which provides cover for them. Lowest record was (2.09 individual $\mathrm{ha}^{-1}$ ) from Pathial Pahar that was a pure natural forest but have disturbance because of road construction around it during the study period. By calls method, highest density was at Dhial (2.45 individual $\mathrm{ha}^{-1}$ ) that was an open land with natural vegetation around it while lowest calls was recorded from Kalewali (1.10 individual ha $\left.{ }^{1}\right)$. Population density recorded by sighting and by calls show difference among different sites. A similar study carried in the agricultural land and wetlnd in the Faisalabad (Central Punjab, Pakistan) utilizing call count method, suggested average densities of 395 birds/ $\mathrm{km}^{2}$ having range from 90 - 655 birds for the Grey francolin did not tried to give density values [30].

The results indicated that Grey francolin prefers areas with vegetation cover and water source which provide better habitat to live in a particular place. These findings are supported by [31] proposed that high density of wild Grey Partridge (Perdix perdix) were related with the presence of herbaceous land, unmanaged wild areas and farm land around it in Prague, the Czech Republic. Moreover, estimations of density, analysis of home range, sampling of weed seed and study of plant structure factors affect the francolin's habitat preference.

Transect sampling and call counts have been utilized for population studies in different francolin species $[32,33,34,28,35]$ to reach at some reliable estimates on the populations. Call counts in spring season were considered as more dependable sign to record the breeding pairs/ birds in population of Grey partridge (Perdix perdix) [36], though such estimates were not considered reliable for other parts of the year due to different climatic conditions. The technique of counting the birds through call affected by changes in season, temperatures, conditions of availability of habitat and food, male activity of reproduction as well as density of males [37, 38]. Such problems have been addressed earlier in call count method as relevant to pheasants $[36,37,39]$. The number of the calling birds has been reflected by call counts, and therefore stated as the frequency of calling males $[40,41]$ or birds in pair form $[42,43]$, of distinct bird species. However, under the conditions of Salt Range, in CSWS and DDGR, in scrub forest the sighting on the transect line for estimations of population seems to be a more reliable method particularly, when the width of the transect belt is limited. Results obtained by calls count are different from the results of direct sightings. This difference may be due to camouflage ability of the grey francolin in different conditions.[ 7] concluded that sightings of the francolins species, living under thick cover of plants, mainly based upon searching a shelter along some vegetation for its protection, and possessing shy behavior under a higher level of disturbance adds difficulties in the transect sightings. During the study, groups of 4 to 12 francolins were observed in CSWS and DDGR, particularly shortly before breeding season. [3, 29] also reported that during non-breeding season, Grey francolins are mostly found in coveys form of 4-8 birds or family groups were also known, which during breeding season makes pairing. Populations of Grey francolin recorded from CSWS were found higher as compared to DDGR, probably because of more protection of the area as sanctuary, 
where grey francolin assumed more protected.

According to present study, being an important habitat of Grey francolin, Salt Range (CSWS and DDGR), needs more attention through formulation of an effective conservation plan for the species. Habitat degradation activities as agricultural intensification/fuel wood collection should be controlled in its habitat. Land encroachment and clearing for the purpose of commercial poultry farming, housing schemes, and other business oriented disturbances must be checked and prohibited Illegal hunting of the species must be strictly prevented through public awareness and also by observing and implementing the Punjab Wildlife Act and Rules 1974. Shooting needs to be regulated by an official body to ensure sustainable harvests of grey francolin in CSWS and DDGR, Salt Range. Wildlife staff should make more efficient and effective efforts for the protection of wildlife in general and Grey francolin in particular to conserve this precious game bird, sustaining its healthy population in this region.

\section{Acknowledgements}

Authors are grateful to Higher Education Commission of Pakistan for providing financial support for conducting this research study. Thanks are also to Idea Wild US Organization for providing some field equipment for the study.

\section{Authors' contribution}

Conceived and designed the experiments: $\mathrm{S}$ Khalil. Performed the experiments: S Khalil \& M Anwar. Analyzed the data: S Khalil \& M Anwar. Contributed reagents/materials/analysis tools: S Khalil, M Anwar \& I Hussain. Wrote the paper: S Khalil.

\section{References}

1. Khan A A, Khan R, Ullah A M A, Mahmood J A \& Sheikh K M (1996). Conservation Perspectives of the Imperial Aquila heliaca and Steppe Eagle Aquila nipalensis in Pakistan. Meyburg. B-U. \& R. D. Chancellor eds. Eagle Studies World Walking Group on Birds of Prey (WWGBP) Berlin, London \& Paris. 3 p.

2. Mirza Z B \& Wasiq H (2007). A field guide to birds of Pakistan. Published by WWF- Pakistan, Bookland, Lahore. 366 p.

3. Grimmett R, Roberts $T$ \& Inskipp I (2008). Birds of Pakistan. Christopher Helm, London Yale University Press, New Heaven. 256 p.

4. Roberts T J (1991). The birds of Pakistan. Non-Passriformes. Vol. I. Oxford University Press, Karachi, pp. 232-233.

5. IUCN (2013). Red List of Threatened Species. Downloaded July, 18, 2015 at http://www.iucnredlist.org.

6. Del Hoyo, Elliot J A \& Sargatal J (1994). Handbook of the birds of the world. In Lynx (ed.), New world Vultures to Guineafowl. Barcelona. pp. 412-567.

7. Fuller A R, Caroll P J \& McGowan (2000). Partridges, Quails, Francolins, Snowcocks, Guinefowl and Turkeys. Status survey and conservation action plan 2000-2004. WPA/BirdLife/SSC Partridges, Quails and Francolin Specialist Group. IUCN. The World Conservation Union, Gland, Switzerland. $63 \mathrm{p}$.

8. Ali S \& Ripley S D (1983). Handbook of the Birds of India and Pakistan. Oxford Univ. Press, Delhi, India.

9. Islam K (1999). Erckel's Francolin (Francolinus erckelii), Black Francolin (Francolinus francolinus), Grey Francolin (Francolinus pondicerianus). Birds of North America, $23 \mathrm{p}$.

10. Rasmussen P C \& J C Anderton. 2005. Birds of South Asia: the Ripley Guide. Smithsonian Institution and Lynx Editions, $121 \mathrm{p}$.

11. Beg M A \& Qureshi J I (1972). Birds and their habitats in the cultivated areas 
of Lyallpur district and vicinity, Pakistan J Agric Sciences 9: 161-166.

12. Mian A (1995). Grey partridge demands intensive study. WPA News, No. 1: 2.

13. Khan R A (1997). Status and ecology of Black and Grey Francolin in agricultural land in the Punjab, Pakistan, WPA News, 52: 30-34.

14. Sharma I K (1983). The Grey Partridge (Francolinus pondicerianus) in the Rajasthan desert. Annals of Arid Zones, 22 (2): 117.

15. Chaudhry A A \& Bhatti M N (1992). Biology of Grey Francolin (Francolinus Pondicerianus) in the Central Punjab Plains. In: Proc. $12^{\text {th }}$ Pakistan Cong. Zool. Zoological Soci. Pakistan, Lahore, pp. 161-162.

16. Bird Life International. (2015). Francolinus pondicerianus. In: The IUCN Red List of Threatened Species.www.iucnredlist.org.

17. King J \& Vincent S T D (1993). Pakistan a Travel Survival Kit. $4^{\text {th }}$ ed. Lonely Planet Publications. Hawthorn. Australia.

18. Awan G A (1998). Ecology of Punjab Urial (Ovis vaginei Punjabiensis) in the Salt Range, Punjab. (Unpublished) M. Phil. Thesis. Quaid-i-Azam Univ. Islamabad, Pakistan: 78 p.

19. Azam M M, Nazar A Q \& Abbas N (2008). Some observations on the population Status of Punjab Urial (Ovis vignei punjabiensis) in district Chakwal. Rec. Zool. Surv. Pak. 18: 1-3.

20. Chaudhry A A, I I Agha A Hussain R Ahmad \& M Hameed (1997). Biodiversity in a typical sub-mountainous protected area Chumbi Surla Wildlife Sanctuary, Punjab, Pakistan. In: Mufti S A, C A Woods \& S A Hasan (eds.), The Biodiversity of Pakistan. Pak. Mus. Nat. Hist. Islamabad. pp. 63-80.
21. Burnham K P, Anderson D R \& Laake J L (1980). Estimation of density from line transects sampling of biological populations. Wildl Monograph 72: 1-202.

22. Javed S R \& Kaul (2000). Field methods for bird surveys, Bombay Natural History Society, Department of Wildlife Science, Aligarh Muslim University, Indian Bird Conservation Network, World Pheasant Association.

23. Sokal R R \& Rohlf F J (2000). Biometry. The Principals and Practice of Statistics in Biological Research. W. H. Freeman and Company, New York, USA. $887 \mathrm{p}$.

24. Buckland S T, Russell R E, Dickson B G, Saab V A, Gorman D G \& Block W M (2009). Analysing designed experiments in distance sampling. J Agri Biol and Env Stat 14: 432-442.

25. Fewster $\mathrm{R} \mathrm{M}$, Buckland $\mathrm{S} \mathrm{T}$, Burnham K P, Borchers D L, Jupp P E, Laake J L \& Thomas L (2009). Estimating the encounter rate variance in distance sampling. Biometrics, 65; 225-236.

26. Thomas L, Buckland S T, Rexstad A, Laake J L, Strindberg S, Hedley S, Bishop J R B, Marques T A \& Burnham K P (2010). Distance software: Design and analysis of distance sampling surveys for estimating population size. $J$ Appl Ecology 47: 5-14.

27. Mian A \& Ghani U I (2007). MacroBiota variation under human protection in desert ecosystem of Cholistan, Pakistan. $J$ Hum Ecology 21 (3): 163-172.

28. Khan W A (2010). Studies on the comparative ecology of the South Persian Black partridge, (Francolinus francolinus henrici), and the Northern Grey partridge, (Francolinus pondicerianus interpositus), in Lal Suhanra National Park, Bahawalpur, Punjab, Pakistan. (Unpublished) Ph.D. Thesis. PMAS-Arid Agri. Univ. Rawalpindi, Pakistan.238 p. 
29. Weijeymohan S, Vandercone $\mathrm{R}$ \& Santiapillai (2003). Observation on the Grey Partridge (Francolinus pondicerianus) in the vicinity of Giant's Tank, Sri Lanka. PQF News 19:11-143. 30. Ullah H (1991). Studies on the biology, habitat, distribution pattern and food of Grey Partridge (Francolinus pondicerianus) in Tehsil Faisalabad, (Unpublished), MSc. Thesis. Univ of Agri, Faisalabad. 182 p.

31. Salek M, Marhoul P, Pinti J, Kopecky T \& Slaby L (2004). Importance of unmanaged wasteland patches for the grey partridge (Perdix perdix) in suburban habitats. Acta Oecol 25(1-2): 23-33.

32. Abbasi F \& Khan J A (2004). Abundance and habitat use of Grey Francolin, Francolinus pondicerianus, in Gursikaran Forest, Aligarh district, Utter Predesh, India. 3rd Internat. Galliformes Symp., India.

33. Mahmood S, Mahmood T, Rais M, Qureshi I Z \& Nadeem M S (2010). A Comparative Study on the Populations and Habitats of the Grey Francolin (Francolinus pondicerianus) and the Black Francolin (FrancolinFrancolinus) francolinusin Lehri Nature Park, Punjab, Pakistan. Podoces 5(1): 42-53.

34. Hussain I, Nisa A \& Khalil S (2012). Population biology of Grey Francolin (Francolinus pondicerianus) in agroecosystem of the pothwar pleatue, Pakistan. J Chin Birds 3(2) 91-102.

35. Weigand J P (1977). Hungarian Partridge in north central Montana. P-R Projects W-91-R-12 and W 120-R- 1-8, Montana Dept. of Game and Fish, 361 p.
36. Gaston A J (1980). Census Techniques for Himalayan pheasants including notes on individual species. $J$ World Pheasant Association (5): 40-53.

37. Davison G W H (1983). Behaviour of the Malaya Peacock Pheasant (Polyplectron malacense) J Zool London. 201: $57-65$.

38. Young L, Garson P J \& R Kaul (1987). Calling behaviour and social organization in the Cheer Pheasant: Implications for survey technique. $J$ World Pheasant Association 12: 40-43.

39. Picozzi N (1987). Observation on the ecology and behaviour of the Koklass Pheasant in Pakistan. J World Pheasant Assoc 4: 52-71.

40. Nijman V (1998). Habitat preference of Great Argus Pheasant (Argusianus argus) in Kayan Mentarang National Park, East Kalimetan, Indonesia. J Ornithology 139: 313 - 323.

41. Winarni N L, O’Brien Carro J P \& Kinnaird M F (2009). Movements, distribution, abundance of Great Argus Pheasants (Argusianus argus) in a Sumatran Rainforest. The Auk 126 (2): $341-350$.

42. Panek M (2005). Demography of Grey Partridge (Perdix perdix) in Poland in the years 1991- 2004: Reasons of population decline. Eur J Wildl Resource 51: 14-18.

43. Bealey C, P McGowan \& H A Rayaleh (2006). Dijbouti Francolin Conservation Project: Report on second Phase. World Pheasant Association, UK. $13 \mathrm{p}$. 